\title{
Upaya Mengembangkan Nilai-Nilai Kerjasama Melalui Penerapan Permainan Tradisional Bakiak Dan Gatrik
}

\author{
*Nova Suci Febriani ${ }^{1}$, Dian Budiana ${ }^{1}$ \\ ${ }^{1}$ Program Studi Pendidikan Guru Sekolah Dasar Pendidikan Jasmani, \\ Fakultas Pendidikan Olahraga dan Kesehatan, Universitas Pendidikan Indonesia \\ email : nova_suci@student.upi.edu
}

\begin{abstract}
Abstrak
Penelitian ini dilatarbelakangi oleh rendahnya nilai-nilai kerjasama dalam aktivitas pembelajaran pendidikan jasmani. Tujuan penelitian ini untuk mengetahui apakah pembelajaran tradisional bakiak dan gatrik dapat membangun nilai kerjasama (pada siswa kelas V SDN Gegerkalong Girang 1-2) yang berjumlah 31 siswa, yaitu 12 laki-laki dan 19 perempuan. Metode yang digunakan dalam penelitian ini adalah Penelitian Tindakan Kelas (PTK) dengan menggunakan dua siklus dan masing-masing siklus terdapat dua tindakan, data penelitian ini diambil dengan menggunakan lembar pengamatan (observasi). Hasil observasi awal menunjukkan bahwa nilai kerjasama siswa masih terlihat rendah dalam pembelajaran, hal ini ditunjukkan dengan nilai-nilai kerjasama sebesar 39,35\% yang seharusnya $75 \%$ dari seluruh aspek. Selanjutnya hasil siklus I tindakan I dengan nilai sebesar 49,64\%. Kemudian setelah diadakan hasil siklus I tindakan 2 dengan memberikan treatment yaitu dengan menambahkan peraturan baru dan memberikan reward, sehingga siswa sangat antusias terhadap permainan tradisional maka dari itu perolehan nilai-nilai kerjasama meningkat menjadi $57,42 \%$. Selanjutnya hasil siklus 2 tindakan I didapatkan nilai kerjasama menjadi 69,42\%. Pada akhirnya hasil siklus 2 tindakan 2 kembali meningkat dengan nilai persentase 80,05 \% . Setelah melalui dua siklus rata-rata nilai-nilai kerjasama dalam permainan tradisional mengalami peningkatan yang signifikan. Kesimpulan penelitian ini adalah adanya peningkatan nilai-nilai kerjasama melalui penerapan permainan tradisional
\end{abstract}

Kata kunci: Pendidikan Jasmani, Permainan Tradisonal, Kerjasama

*Nova Suci Febriani adalah lulusan Program Studi PGSD Penjas, Departemen Pendidikan Olahraga, Fakultas Pendidikan Olahraga dan Kesehatan, Universitas Pendidikan Indonesia. 


\title{
Efforts To Develop A Cooperation Value By Applying Bakiak And Gatric Traditional Games
}

\begin{abstract}
This study is motivated to find out whether the students can build cooperation value by applying traditional games. The object of this study is to build cooperation value in traditional games learning to find out how far the implementation of playing games in building cooperation value is (in students 5th grade of Gegerkalong Girang 1-2 Elementary School) totalling 31 studets, the 12 male and 19 famale. The method used is Classroom Action Research (CAR) using two cycles. The result of preliminary observation shows that the value of student cooperation looks low in learning. It is shown by the values of cooperation average percentage $39.35 \%$ which should be $75 \%$ of all aspects. Furthermore, the result of cycle I action I is 49.64\%. Then the result of cycle I action 2 is $57.42 \%$. The result of cycle 2 action I is 69,42\%. Next, the result of cycle 2 action 2 is $80.05 \%$. After going through two cycles, the average values of cooperation in the traditional games has increased significantly. The conclusion of this study is that the value of students cooperation by applying traditional games has increased.
\end{abstract}

Keyword: Physical Education, Traditional Hames

\section{PENDAHULUAN}

Pendidikan jasmani merupakan proses pendidikan yang dilakukan melalui aktivitas gerak tubuh manusia. Pendidikan jasmani pada hakikatnya adalah proses pendidikan yang memanfaatkan aktivitas fisik untuk menghasilkan perubahan holistik dalam kualitas individu, baik dalam hal fisik, mental serta emosional Mahendra (2012, hlm.3). Dari definisi ahli di atas bahwa dengan pendidikan jasmani siswa dapat mengembangkan kualitas gerak melalui aktivitas fisik dan mengatur emosi yang terdapat di dalam dirinya.

Perlu di pahami bahwa mata pelajaran Pendidikan Jasmani di Sekolah Dasar merupakan bagian integral dari bagian keseluruhan yang bertujuan 
untuk mengembangkan aspek kebugaran jasmani, gerak, keterampilan berpikir ktitis, keterampilan sosial , stabilitas emosional, aspek pola hidup sehat dan pengenalan lingkungan bersih melalui aktivitas jasmani, olah raga dan kesehatan terpilih yang di rencanakan secara sistematis dalam rangka mencapai tujuan pendidikan nasional, sehingga penjas merupakan pendidikan yang konkrit tentang berbagai makna nilai,nilai sosial. Nilai saling menghargai, Kerjasama, saling berkompetisi dengan sehat, tidak kenal lelah, pantang menyerah dan bersahabat merupakan nilai-nilai sosial yang di dapan di dalam mata pelajaran penjas di Sekolah Dasar.

Salah satu untuk cara untuk menanamkan nilai tersebut adalah melalui permainan tradisional. Karena secara langsung para peserta akan belajar nlai-nilai tersebut, dan tanpa di sadari nilai-nilai tersebut akan mereka terapkan dalam permainan tradisional sehingga nilai-nilai kebaikan akan terus terjaga dengan baik sehingga dapat di simpulkan bahwa permainan tradisional perlu di lestarikan sebagai cara untuk mempertahankan nilai nilai yang ada di dalamnya. Contonya bagaimana pembentukan nilai,moral, dan karakter, disamping menstimulasi aspek motorik, kognitif,emosi,sosial dalam permainan tradisional.

Dalam upaya mencapai tujuan dari pembelajaran pendidikan jasmani, banyak macam permainan yang bisa di ajarkan kepada anak didik sesuai dengan ruang lingkup pendidikan jasmani yang di antaraya meliputi permainan ataupun melalui suatu kecabangan olahraga yang di tunjukan untuk kepentingan pendidikan. Bermain dan anak merupakan kesatuan yang tidak dapat di pisahkan, dengan permainan siswa bergerak bebas 
dengan perasaan senang karena tidak terdapat teknik gerak yang dianggap sulit.

Sikap kerjasama dalam permainan sangat penting karena tanpa kerjasama permainan tidak akan berjalan dengan baik, Kusnadi. H (2012, hlm, 43) Kerjasma diartikan sebagai dua orang atau lebih untuk melakukan aktivitas bersamayang dilakukan secara terpadu yang diarahkan kesuatu target atau tujuan tertentu. Maka dari itu dalam suatu permainan berkelompok kerjasama dibutuhkan untuk mencapai suatu target atau mencetak poin demi meraih kemenangan. Penelitian ini bertujuan untuk mengetahui apakah permainan tradisional (gatrik dan bakiak) dapat mengembangkan nilai-nilai kerjasama pada siswa kelas V Sekolah Dasar.

\section{METODE}

Tujuan penelitian ini untuk mengetahui apakah pembelajaran tradisional bakiak dan gatrik dapat membangun nilai kerjasama (pada siswa kelas $\mathrm{V}$ SDN Gegerkalong Girang 1-2) yang berjumlah 31 siswa, yaitu 12 laki-laki dan 19 perempuan. Metode yang digunakan dalam penelitian ini adalah Penelitian Tindakan Kelas (PTK) dengan menggunakan dua siklus dan masing-masing siklus terdapat dua tindakan, data penelitian ini diambil dengan menggunakan lembar pengamatan (observasi). 


\section{HASIL DAN PEMBAHASAN}

Tabel 1

Perolehan Nilai Persentase Rata-rata kerjasama Dari Setiap Tindakan

\begin{tabular}{|l|l|l|}
\hline \multicolumn{1}{|c|}{ Kegiatan yang dilakukan } & \multicolumn{1}{|c|}{$\begin{array}{c}\text { Rata-rata penilaian hasil } \\
\text { kerjasama }\end{array}$} & \multicolumn{1}{c|}{ Keterangan } \\
\hline Pra Observasi & $39,35 \%$ & Belum Tuntas \\
\hline Siklus I Tindakan 1 & $40,64 \%$ & Belum Tuntas \\
\hline Siklus I Tindakan 2 & $57,42 \%$ & Belum Tuntas \\
\hline Siklus II Tindakan 1 & $69,42 \%$ & Belum Tuntas \\
\hline Siklus II Tindakan 2 & $80,05 \%$ & Tuntas \\
\hline
\end{tabular}

Berdasarkan hasil penelitian dari mulai observasi awal sampai dengan siklus II (tindakan 2), diketahui bahwa nilai-nilai kerjasama dengan penerapan permainan. Adapun data dan rangkuman hasil akhir penelitian dari observasi awal sampai dengan siklus dua tindakan dua dapat digambarkan dalam grafik berikut:

Tabel 2

Perolehan Nilai Persentase Rata-rata kerjasama Dari Setiap

Tindakan

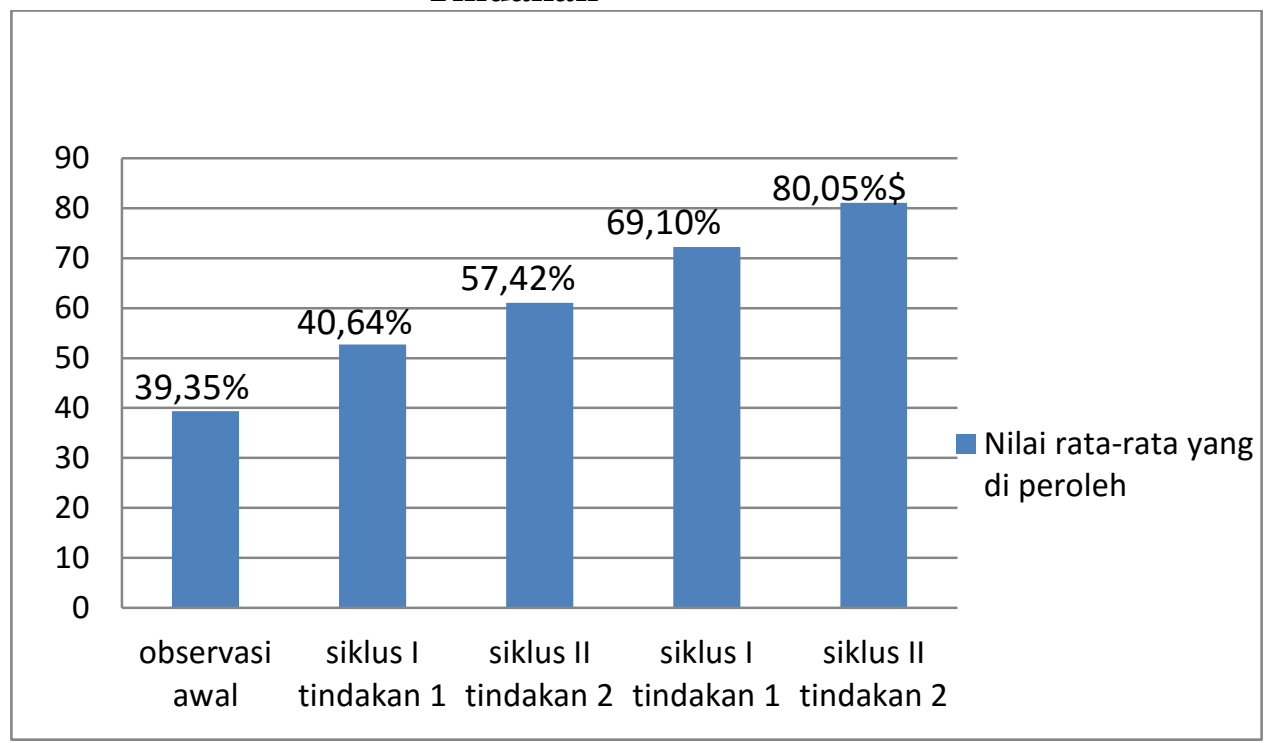


Adapun jika digambarkan dalam bentuk kurva nilai yang diketahui bahwa nilai-nilai kerjasama melalui penerapan permainan. Adapun data dan rangkuman hasil akhir penelitian dari observasi awal sampai dengan siklus dua tindakan dua terdapat pada Gambar 1.

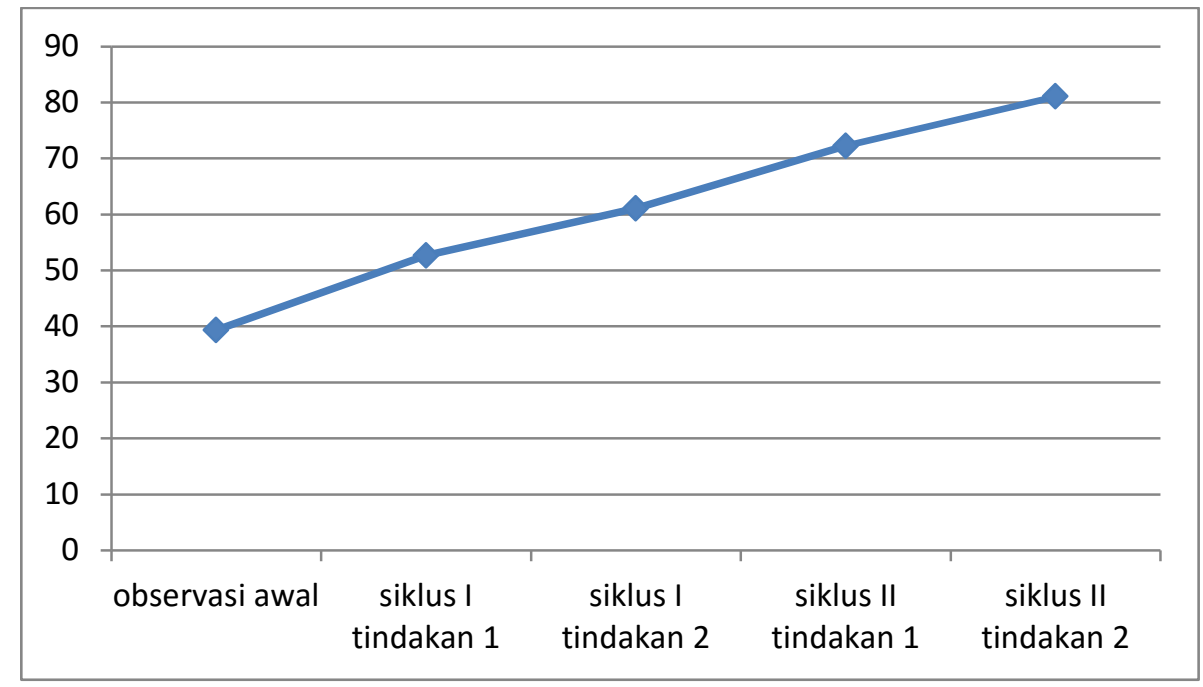

Gambar 1

Perolehan Nilai Persentase Rata-rata kerjasama dari Setiap Tindakan

Berdasarkan hasil yang telah didapat selama proses penelitian, maka diskusi hasil penelitian temuan dari penelitian ini adalah bahwa menerapkan unsur permainan sangat cocok untuk meningkatkan kerjasama pada pembelajaran pendidikan jasmani. Setiap tindakan dalam penelitian juga mengalami peningkatan. Hal tersebut dikarenakan tingkat ketercapaian nilai yang diperoleh dari penelitian memuaskan yaitu dengan persentase rata-rata pada Siklus II (Tindakan 2) sebesar 80,05\%.

Berdasarkan hasil penelitian didapatkan bahwa permainan tradisional gatrik dan bakiak, memberikan pengaruh terhadap pengembangan nilai- 
nilai kerjasama. Hal ini sesuai dengan pendapat yang di kemukakan oleh Bigo el tal (dalam sukintaka 1992, hlm, 15) menjelaskan bahwa: "permainan tradisional akan mendasari kerjasama, taat kepada peraturan, pembinaan watak jujur dalam bermain dan semua itu akan membentuk prilaku fair-play (jujur sifat kesatria, atau baik dalam bermain)". Untuk kedepannya permainan tradisional ini sangat baik di ajarkan dalam pembelajaran pendidikan jasmani di sekolah dasar karna mampu mengembangkan nilai-nilai dan karakter anak menjadi lebih baik terutama dalam hal kerjasama siswa". Berdasarkan hasil observasi, data yang didapatkan adalah :

a. Siswa dapat bekerjasama dengan baik saat pembelajaran permainan tradisional gatrik dan bakiak

b. Siswa dapat mengembangkan kreativitas dalam permainan tradisional gatrik dan bakiak

c. Siswa dapat meningkatkan rasa percaya diri agar dapat mudah beradaptasi dengan lingkungannya.

d. Siswa mempunyai rasa empati, toleransi dan sosialisasi.

\section{KESIMPULAN}

Kerjasama merupakan kesanggupan untuk melakukan usaha secara bersama-sama untuk mencapai tujuan bersama. Berdasarkan hasil penelitian yang penulis teliti terbukti bahwa dengan melalui permainan tradisional (bakiak dan gatrik) dapat memberikan peningkatan yang baik terhadap nilai-nilai kerjasama siswa, hal ini tercapai setelah dilakukan selama dua kali siklus yang setiap tindakannya terdiri dari dua tindakan dalam pembelajaran pendidikan jasmani pada siswa kelas V SDN 
Gegerkalong 1-2. Disetiap tindakannya, menunjukan adanya peningkatan nilai-nilai kerjasama siswa, terlihat dari sikap-sikap siswa yang mengalami perubahan yang lebih baik, terjalinnya interaksi yang baik dengan kawan ataupun lawan, tolong-menolong, saling memberi dukungan dan mentaati peraturan yang dibuat oleh guru. Yang terpenting dari penelitian ini adalah siswa mampu memahami dan menerapkan pentingnya nilai-nilai kerjasama dalam kehidupan shari-hari.

Berdasarkan hasil analisis data penelitian yang penulis teliti terbukti bahwa dengan menerapkan permainan tradisional (bakiak dan gatrik) mampu memberikan pengaruh terhadap peningkatan nilai-nilai kerjasama siswa kelas V SDN Gegerkalong Girang 1-2. Dalam hal ini hampir seluruh siswa dapat memahami dan mengetahui apa yang diberikan oleh guru sebagai peneliti dan tidak mengalami kejenuhan dalam pembelajaran pendidikan jasmani, serta tercipta saat mereka belajar dalam suasana yang menyenangkan dan senang untuk belajar. 


\section{DAFTAR PUSTAKA}

Mahendra, A. (2012). Asas dan Falsafah Pendidikan Jasmani. Bandung: FPOK UPI Bandung.

Sukintaka (1992). Teori Bermain. Departemen Pendidikan dan Kebudayaan Direktorat Jendral Pendidikan Tinggi Proyek Pembinaan Tenaga Kependidikan. Bandung

Wuest \& Bucher (1995) Cooperative Learning, Ujungberung, Bandung : Nusa Media

Sumber Lain :

http://Zidnyfahma.blogspot.co.id/2013/09/pendidikan jasmani.html?m=1.Di akses 13 januari 2017

Kusnadi (2012). Pengertian Kerjasama. [Online]. Tersedia :dihttp://idshoovng.com

1943506-pengertian-kerjasama.diaksespada 12 Februari 2017 pukul 14.20 WIB 